\title{
Ideological Basis of Education
}

\author{
Irina Verezgova \\ Moscow Technological University \\ Moscow, Russia \\ E-mail: viv-vera@mail.ru
}

\author{
Svetlana Tikhonova \\ Moscow Technological University \\ Moscow, Russia \\ E-mail: svetlanavt@list.ru
}

\begin{abstract}
The paper looks at the need for moral and ethical education components, with emphasis on the relevance of patriotic upbringing. The authors underscore the negative effects of de-ideologization and make a conclusion on the pressing need to create a national ideological strategy.
\end{abstract}

Keywords-education; upbringing; state ideology; conservatism; patriotism; morality; value system

\section{INTRODUCTION}

In our opinion, developing a moral mindset in students is one of the pillars of higher education which must instill in young people a "system of values and purposes", i.e. an ideology. From our standpoint, education must not be devoid of ideological content. Belief in a certain ideal and commitment to a common value system advocated by a group of people throughout their life space is an essential pre-requisite for building and maintaining a closely-knit society capable of dealing with present-day challenges.

\section{THE ROLE OF THE IDEOLOGICAL STRATEGIES IN EDUCATION}

The issue here is certainly not a uniform religious system or a single political ideology. We are referring primarily to a common system of values, ethical principles and shared moral commandments as a unifying concept for different religions and ideologies. These are the fundamental components appearing as a set of universal notions shared and understood by the majority and constituting a frame of reference for a larger part of the society. While holding people together, these fundamental concepts develop a sense of unity in individuals of different confessions, occupations, etc. and underlie the sense of community enabling people to co-exist within a specific society or state.

We believe that such uncontestable values must include love for the Motherland, humanism, tolerance to opinions and ideas that are contrary to one's belief, awareness of the value and uniqueness of human life, and so on. As a consequence, education programs must promote commitment to the preservation of the home country's historical and cultural assets, continuity of tradition, and patriotic spirit. Good knowledge of national history and awareness of uniqueness and diversity of the country's artistic wealth contribute to an individual's comprehension of their position in the modern world.

Today, education is showing a distinct tendency towards specialization with a clearly prevailing competence-based approach. While helping young people to develop their application-oriented knowledge, skills and abilities, the educational process leaves progressively less room for the moral and humanistic components.

We recall Bertolt Brecht's message to researchers: “In the course of time you are likely to discover all that may be discovered, but your progress in science will only take you farther away from the mankind. The gap between you and the mankind may become so wide that some day your triumphant announcement about a new discovery will be received with a cry of fear"1. Any scientific discovery or engineering invention makes no sense if it is devoid of humanistic value and the scientist's responsibility before mankind. For this very reason, the formation of a moral mindset is the keystone of the education system.

The Nominal Decree "On the set-up of schools" (Item 1, Chapter 1) that Alexander the First addressed to the Russian Senate on 24th January 1803 stated that "the schooling must provide moral education of citizens according to the duties and benefits specific to each social stratum" 2 . Nowadays, the effects of globalization often translate into the unification of education and are becoming all the more noticeable in many countries. A global talent market is emerging, with experts travelling worldwide in search of employment where they can put their knowledge and skills to best use. One must remember that the education system is always national but never international. Each country allocates budgets for education and trains experts, primarily for its own needs and purposes. Availability of skilled human resource is a key to economic growth and social advancement of any country. However, if most of the skilled professionals choose to apply their talents and abilities abroad, who will support their home country and help it create a material and moral basis for further development?

In our view, the issue can be addressed in the first place by strengthening the humanistic component of education, leveraging on tradition and historical experience of instilling a loyal and positive attitude towards the mother country.

The Ministry of Education and Science launched the National Program "Promotion of patriotism among the Russian Federation citizens for 2011-2015", followed by a similar program for 2016-2020. The topic was also raised in

\footnotetext{
${ }^{1}$ Brecht B. Life of Galileo. - M., 1972. P.777.

${ }^{2}$ Nominal Decree of $24^{\text {th }}$ January 1803 addressed to the Senate "On the setup of schools", Iteml, Chapter 1.
} 
the recent Decree No. 683 signed by President Putin on 31st December 2015 and setting forth the basic ideological principles and a new national security strategy of the Russian Federation. This conceptual document states that "Russia is restoring its traditional ethical and moral values and the younger generation is displaying a positive perception towards Russia's history. The civil society is getting consolidated around common nation-building values, such as freedom and independence of Russia, humanism, peace and amity between nations, harmony of cultures of the multiethnic nation, respect for family and confessional traditions, and patriotism"3.

It is a well-known fact that any education, including patriotic upbringing, is a way of preparing a nation for fulfilling its civic duty and not an end in itself. However, fulfilment of the civic duty, rather than being the ultimate goal, is a driver for the state to develop legitimately and effectively. Thus, it guarantees the exercise of rights and freedoms by its citizens.

According to Russian legal experts, the state's primary objective is to ensure normal and natural development of society based on internal economic (material) and moral (humanitarian) factors, for example, free development of an individual and a civil society (moral factor) [5]. Civic identity is a hot-button issue in today's divided world with co-existing sovereign states, each having its specific political, social and moral systems. Civic responsibility for the future of the home country and its future generations is a highly topical issue in the present context of global standoff.

We conclude that the upbringing of the younger generation aims to create beneficial human development conditions. In reference to patriotic upbringing, we do not refer to an abstract notion of education. We imply that education should rest upon a rich cultural and moral wealth of a historically established state. The idea behind truly patriotic upbringing is that it should focus on long-standing cultural and moral features which can help effectively deal with a specific issue, rather than attempt to align the education principles with standards or practices commonly accepted in the world. Any reference to 'patriotism' made in other contexts would be 'phantom' usage of the term making no sense.

Moral education deserves special attention when one addresses the formation of ideological values. "Patriotic" upbringing constitutes a large part of moral education. It is only thanks to moral education that an individual can build a set of value-related criteria, such as the essence and basis of human strength, develop an ability for selecting a correct, moral and the most efficient path of development, and learn to resist perilous, counter-productive and destructive ideas. An individual is unable to fight back alien values imposed through enticing ideas or stereotypes unless they have their own mentality-specific ideas underlying a value system of their own. This brings to light the need to create our own

\footnotetext{
${ }^{3}$ Garant.ru: http://www.garant.ru/hotlaw/federal/688504/\#ixzz3wZfMMqB
} N. "patriotic" ideology, for ideology is a set of ideas that more or less fully describe an individual's frame of reference.

Thus, the development of the ideological strategy is an issue related to both national security and ability to safeguard national interests. Actually, the question is whether the state is viable and capable of meeting the current geopolitical, ideological and cultural challenges. For this reason, creation of a patriotic ideology has become an overriding issue that determines the fate of our statesmanship. A strong moral framework and a system of ideological references are indispensable for overcoming the system-wide crisis and making a breakthrough in the 21 st century.

\section{THE NECESSITY OF STATE IDEOLOGY CONCEPTION RENEWAL}

In the 1990s, the notion of "state ideology" was deliberately discredited and associated with the era of totalitarianism. At the time, the Russian political elite headed by President Boris Yeltsin instigated a ban on an any state ideology whatsoever. The Russian Federation Constitution adopted in 1993 states that "In the Russian Federation ideological diversity shall be recognized" (Item 1, Article 13) and that "No ideology may be established as state or obligatory one" (Item 2, Article 13) [5], although it is well known that a state cannot exist without an ideology.

The modern Russian society significantly needs a unifying and consolidating idea. Currently, people unite mostly around some ideological attitudes. We note that Russia's ideological paradigms have gone through several phases of evolution in the last 25 years to result in an ideological pluralism.

However, looking at the life-changing events of the last few years, we discover that the multitude of issues can be resolved by tackling only one, namely, by focusing on enlightened and democratic conservatism. The notion of conservatism as such does not imply the end of evolution. Its primary objective is to guarantee that the traditional and reliable foundations and values are carefully protected. Being aware of obvious drawbacks of conventional conservatism, we believe that today's society should fall back on a new concept of conservatism to be able to survive in the face of imminent global threats, such as an environmental and cultural crisis, increase in crime, etc. National cultural consciousness must play the integrating role in the process.

\section{CONCLUSION}

We note in conclusion that there is an great need for creating and adopting a new ideological paradigm. The short-term priority consists in the consolidation of society as a crucial pre-requisite for dealing with economic challenges that Russia is facing in the second decade of the 21st century. That's exactly why professional training (youth upbringing and education included) is of extremely high relevance today. The challenge can only be met by integrating moral components in the educational process and systematically instilling a moral purpose in the young. 


\section{REFERENCES}

[1] Brecht B. Life of Galileo. - M., 1972. P.777.

[2] Garant.ru: http://www.garant.ru/hotlaw/federal/688504/\#ixzz3wZfM $\mathrm{MqBN}$.

[3] Nominal Decree of 24th January 1803 addressed to the Senate "On the set-up of schools", Item1, Chapter 1.

[4] Constitution of the Russian Federation. - M., 2010. P.7.

[5] Perevalov V.D., Alekseev S.S., Arkhipov S.I. "Theory of the state and law: Textbook". NORMA Publishers, 2011.

[6] For more details, see: http://www.labirint.ru/books/274080/.

[7] Tikhonova S.V. Development of a state ideology in modern Russia//Caspian Region: policies, economics, culture. 2015. No. 2.

[8] Tikhonova S.V. Political culture as a social reform instrument //Experimentum 2013. Collected papers, MSU Department of Philosophy. Pushkino: Center of Strategic Innovations. 2013. P.107114. 